\title{
Using mulch from cover crops to facilitate organic no-till soybean and maize production. A review
}

\author{
Laura Vincent-Caboud $^{1}$ (D) Marion Casagrande ${ }^{2,3} \cdot$ Christophe David $^{1} \cdot$ Matthew R. Ryan $^{4} \cdot$ Erin M. Silva ${ }^{5}$. \\ Joséphine Peigne ${ }^{1}$
}

Accepted: 5 August 2019/Published online: 4 September 2019

(C) INRA and Springer-Verlag France SAS, part of Springer Nature 2019

\begin{abstract}
Sustainable cropping systems that balance agricultural productivity and ecological integrity are urgently needed. Overreliance on soil tillage and herbicides to manage weeds has resulted in a number of major environmental problems including soil erosion and degradation, biodiversity loss, and water quality impairment. Combining organic farming and conservation agriculture is a viable alternative to address these challenges. In particular, mulch-based no tillage systems can be used to reduce tillage in organic production, improving soil quality while decreasing labor and fuel requirements. This technique involves planting cash crops directly into terminated cover crops that remain on soil surface and serve as mulch to prevent weeds establishment and protect soil from erosion. Despite potential benefits, adoption of organic mulch-based no tillage is limited due to challenges with cover crop termination, weed suppression, and yields. Here, we (i) review international research on organic mulch-based no tillage systems (soybean and maize), (ii) identify production issues that limit the success of this technique, and (iii) outline research priorities. As result, organic mulch-based no tillage is knowledge intensive and requires advanced planning and careful management of the cover crop. Primary challenges include timely cover crop establishment and termination, nutrient management, reduced soil temperature and moisture at planting, and achieving adequate seed-to-soil contact when planting into thick mulch on soil surface. Long-term research is needed to better understand the effects of this technique production on soil health and on the broader environmental and economic impacts. To increase adoption of organic mulch-based no tillage, future research should focus on (i) screening species and cultivars to identify cover crop and crop combinations that optimize cropping system performance and (ii) developing equipment for improving cover crop termination and seed placement. Research conducted in partnership with farmers will be valuable for developing guidelines and increasing adoption of this technique.
\end{abstract}

Keywords Direct seeding $\cdot$ Organic farming $\cdot$ Residue $\cdot$ Roller-crimper $\cdot$ Weed management

\section{Contents}

1. Introduction

2. Scope of international research on mulch no tillage in organic farming

Laura Vincent-Caboud

lavincent-caboud@isara.fr

1 Department of Agroecology and Environment, ISARA, 23 rue Jean Baldassini, 69364 Lyon, France

2 Quartier Marcellas, ITAB, 26800 Etoile sur Rhône, France

3 Ecodéveloppement, INRA, 84000 Avignon, France

4 School of Integrative Plant Science, Cornell University, Ithaca, NY 14853, USA

5 Department of Agronomy, University of Wisconsin-Madison, Madison, WI 53706, USA
3. How can cover crop and cash crop management optimize organic mulch-based no tillage success?

4. Research agenda for the future

5. Conclusion

References

\section{Introduction}

Faced with the challenge of feeding a growing population, the need to develop sustainable agricultural systems that increase productivity and maintain ecological integrity is increasingly imperative. Organic farming (OF) and conservation agriculture (CA) are strategies to achieve these sustainability goals (FAO 2011). CA relies on three principles aimed at reducing soil erosion and improving soil fertility (Reicosky and Saxton 2006; Hobbs et al. 2008): (1) 
minimal soil disturbance, (2) permanent soil cover, and (3) crop rotation. A primary aim of CA includes the seeding of cash crops without soil disturbance after the previous cash crop harvest (Baker and Saxton 2007). Under the auspices of CA, a variety of reduced tillage (RT) techniques has been developed for arable crops, ranging from reducing tillage depth to modifying planting equipment with coulters to make a seed furrow with no further soil disturbance (Fig. 1). Production systems utilizing conservation tillage, no-till (NT), ridge-till, and mulch-till techniques have increased dramatically in the USA, with demonstrated soil benefits, reliable yields, and economically robust performance of field crops (Pittelkow et al. 2015). USDA's Economic Research Service reported 36 million hectares-or about 40 percent of all US planted cropland-implemented some form of NT management in 2010 , including $34 \%$ of corn, $46 \%$ of soybean, $30 \%$ of cotton, and $48 \%$ of wheat areas within the contiguous 48 states (USDA-ERS 2015).

However, increased use of NT practices has not been observed across OF, which has been criticized for excessive use of tillage for weed management, potentially compromising soil quality and health as well as increasing the risk of water and wind erosion (Carr 2017). Despite the benefits arising from NT practices (e.g., reduced soil erosion, labor costs, and energy consumption) (Teasdale et al. 2007; Triplett and Dick 2008), NT adoption in OF remains limited, mainly due to inadequate weed suppression. Although beneficial from a soil conservation perspective, the dependence of conventional NT on herbicides creates concerns regarding the development of herbicide-resistant weeds and negative environmental impacts, such as reduced water quality and non-target impacts on wildlife (USDA-ERS 2015; Uri 2000; Kniss 2017). These herbicide-related concerns, coupled with the demands of a rapidly growing organic crop production sector (Wyse 1994; Jackson 1997), has forced more farmers and researchers to examine alternative strategies of NT to improve soil health while maintaining high yields and achieving effective weed management (Moyer 2011; Silva and Delate 2017).

Cover crop-based no tillage (CCBNT) has emerged as a possible sustainable alternative to traditional herbicide-based NT practices. CCBNT involves no-till planting cash crops into a cover crop (Figs. 1 and 2) (Triplett and Dick 2008). CCBNT offers benefits of continued cover on soil health and weed suppression through physical barriers, light and nutrient competition, and allelopathic effects, which reduce or eliminate herbicide use (Teasdale et al. 2007). CCBNT encompasses two distinct approaches: living cover-based no tillage (LCNT), which involves the planting of cash crops into a growing cover crop, and mulch-based no tillage (MNT), which involves the planting of cash crops into a cover crop that is mechanically terminated by rolling or mowing to provide mulch (Fig. 1). In many circumstances, planting cash crops into a living cover has failed due to cover crop competition with the cash crop (Hiltbrunner et al. 2007a). As such, research efforts have turned to improving best management practices of MNT without herbicides, relying on the cover crop biomass to create mulch that serves as a physical barrier to protect the soil and suppress weeds (Fig. 2) (Teasdale et al. 2004; Carr et al. 2013).
Fig. 1 Techniques for reducing tillage that have been developed in conservation agriculture

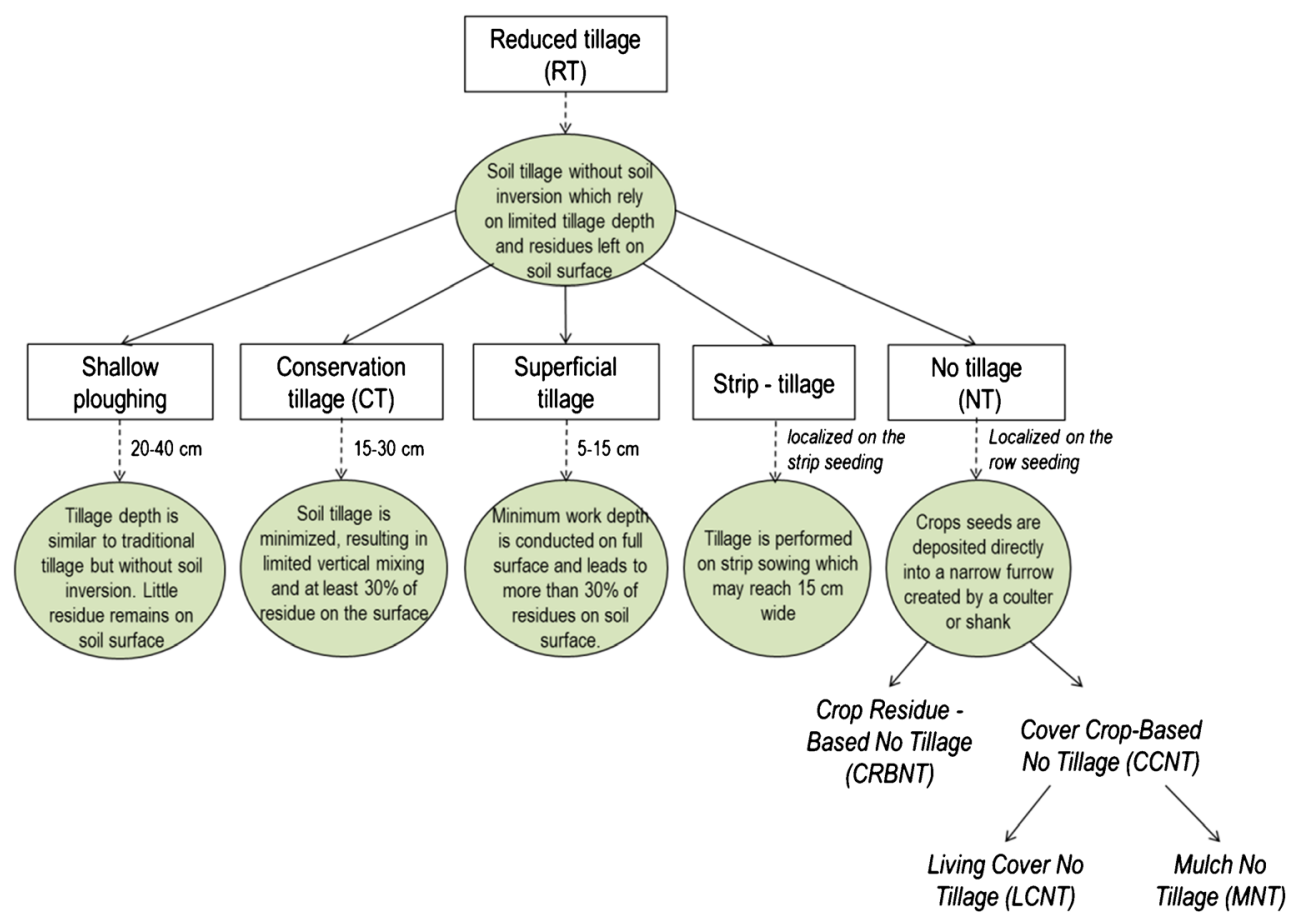




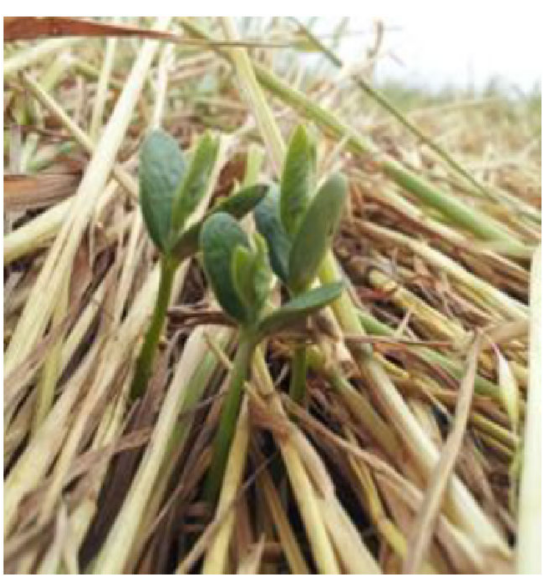

Fig. 2 Soybean emergence through cover crop cereal rye residue left on soil surface that provides physical barrier to prevent weeds development (pictures L. Vincent-Caboud)

While maintaining compliance with the principles and regulations of organic certification programs, MNT can provide an alternative approach to typical organic practices, which often include primary tillage and multiple passes with cultivation equipment for weed management (Mäder and Berner 2012; Silva and Delate 2017). Although MNT is still only practiced on a limited number of farms, both organic and conventional farmers are interested in adopting this technique as a strategy to improve soil quality, reduce labor and fuel use, and decrease reliance on herbicides and mechanical cultivation (Ryan et al. 2003; Bernstein et al. 2011; Casagrande et al. 2015; Crowley 2017). Weed and cover crop management are major challenges for maintaining crop yield in organic MNT. These challenges are due to the lack of knowledge, skills, and equipment needed to optimize cover crop establishment, ensure effective cover crop termination, and successfully establish cash crops (Halde et al. 2017; Wallace et al. 2017; Zikeli and Gruber 2017).

In this paper, we review the international literature related to MNT in organic soybean and maize production, addressing the major issues impeding MNT success and identifying the ongoing challenges to integrating MNT into OF. First, we review studies investigating organic MNT, identifying the underlying principles that govern success. Second, we consider factors that can improve cover crop establishment and termination as well as cash crop planting. Lastly, we discuss the direction of international research and offer suggestions for future research that could facilitate farmer adoption of MNT in OF.

\section{Scope of international research on mulch no tillage in organic farming}

In Europe, MNT research in organic farming is limited, with most studies focusing on LCNT (Weber et al. 2017; Cooper et al. 2016; Mäder and Berner 2012; Vincent-Caboud et al.
2017). Research conducted on clay loam or silty soils has focused on the direct seeding of winter wheat (Triticum aestivume L.), maize (Zea mays L.), quinoa (Chenopodium quinoa Willd), or flax (Linum usitatissimum L.) into living legumes (e.g., clovers species, alfalfa) which often results in unacceptable resource competition with cash crops (Bilalis et al. 2011, 2012; Hiltbrunner et al. 2007a, b; Zikeli and Gruber 2017). For example, NT planting maize into alfalfa resulted in yield losses of $75 \%$ compared to maize that was planted into tilled soil $(p<0.001)$ in Southeastern France (Peigné et al. 2015). This is because alfalfa is a perennial and continued to grow even after a roller-crimper was used to limit competition between alfalfa and maize. In the same location, soybean (Glycine max (L.) Merr.) that was NT planted into rolled cereal rye (Secale cereale L.) yielded only $25 \%$ lower compared with traditional plowing $(p<0.05)$ (Peigné et al. 2015).

Counter to the research trends in Europe, a fair number of MNT research trials have been conducted in the USA (largely on silty loam soils), primarily focused on soybean and maize (Ryan et al. 2011; Silva and Vereecke 2019; Parr et al. 2014; Mischler et al. 2010a; Wells et al. 2015). These studies included a wide range of production research questions, including screening cover crop species, describing the effects of the timing of cover crop rolling and crop seeding on crop performance, weed population and community dynamics, and estimating the energy use, greenhouse gas emissions, and profitability of MNT compared to traditional practices. Several of these studies have documented that no-till planted soybean into rolled cereal rye produces relatively high yields comparable with soybean planted into tilled soil (Clark et al. 2017; Silva and Delate 2017; Wallace et al. 2017). The sowing of maize into terminated legume cover crops (e.g., hairy vetch, Vicia villosa Roth) has also been extensively studied. Results with maize are more variable compared to soybean depending on location and climate, ranging from significant losses over $90 \%$ to yields of approximately $9.0 \mathrm{t} \mathrm{ha}^{-1}$, equal to traditional tillage-based production (Mischler et al. 2010b; Parr et al. 2011).

Organic MNT has also been studied in Canada and has been adapted to a shorter growth season and low temperatures (Beach et al. 2018). Canadian trials integrated MNT into the production of spring wheat, flax, and soybean on sandy loam soil (Halde et al. 2017). Initial trials resulted in NT wheat and flax yields comparable or greater than the regional averages with traditional tillage (Halde et al. 2014; Halde and Entz 2014). However, one persistent challenge with using MNT for small grain production is to effectively suppress small-seeded annual weeds without affecting small grain seedlings, which also have relatively small seeds compared to soybean and maize (Nichols et al. 2015). Organic MNT is also used in South America (Altieri 
et al. 2011), where MNT is widely applied in conventional farming (Derpsch 1998). Researchers have reported on studies related to fertilization strategies, cover crop species performance, and innovative solutions to suppress weeds using electrical current in MNT systems (Penha et al. 2012; Favarato et al. 2014; Landers et al. 2016).

Several studies on organic MNT have been conducted in vegetable production systems (Altieri et al. 2011; Canali et al. 2015; Robb et al. 2018). Compared with grain crops, important differences exist that are related to the shorter growing season of vegetable crops and the more complex crop rotations, which can facilitate organic MNT practices. One potential advantage of MNT in vegetable production is reduced incidence of soil-borne diseases. In this review, however, we focus on organic MNT issues related to grain crops, specifically soybean and maize.

Previous studies have demonstrated that cash crop establishment and resource competition from both surviving cover crops and weeds are primary challenges to achieving acceptable yields (Fig. 3). In light of these ongoing challenges, we address the following key questions regarding the sustainability and suitability of organic MNT:

- Which cover crop management practices optimize weed suppression?

- Which cover crop control strategy best mitigates cover crop competition with cash crops?

- Which cash crop management technique best maintains cash crop yields compared with traditional organic practices?
- Is MNT agronomically, economically, environmentally, and socially sustainable in OF?

\section{How can cover crop and cash crop management optimize organic mulch-based no tillage success?}

\subsection{Cover crop management}

To suppress weeds throughout the entire cash crop season, rapid cover establishment and high cover crop biomass are required (Reberg-Horton et al. 2012; Mirsky et al. 2013). Cover crop management, including cover crop selection, seeding date and rate, termination date, equipment, fertilization, and irrigation, is critical to produce adequate biomass and achieve effective termination. Optimization of these factors can improve weed suppression, soil fertility, and cash crop performance (Mirsky et al. 2012; Schmidt et al. 2019).

\subsubsection{Cover crop species}

The selection of the cover crop species in a given region and crop rotation depends upon cash crop sequence and the lengths of time between cover crop planting, fall dormancy, and spring termination (Moyer 2011). Ideal cover crops for MNT must have certain key traits including adequate fall growth before entering the dormancy period, ability to overwinter, sufficient biomass at termination for weed suppression
Fig. 3 Primary challenges of mulch no tillage under organic conditions

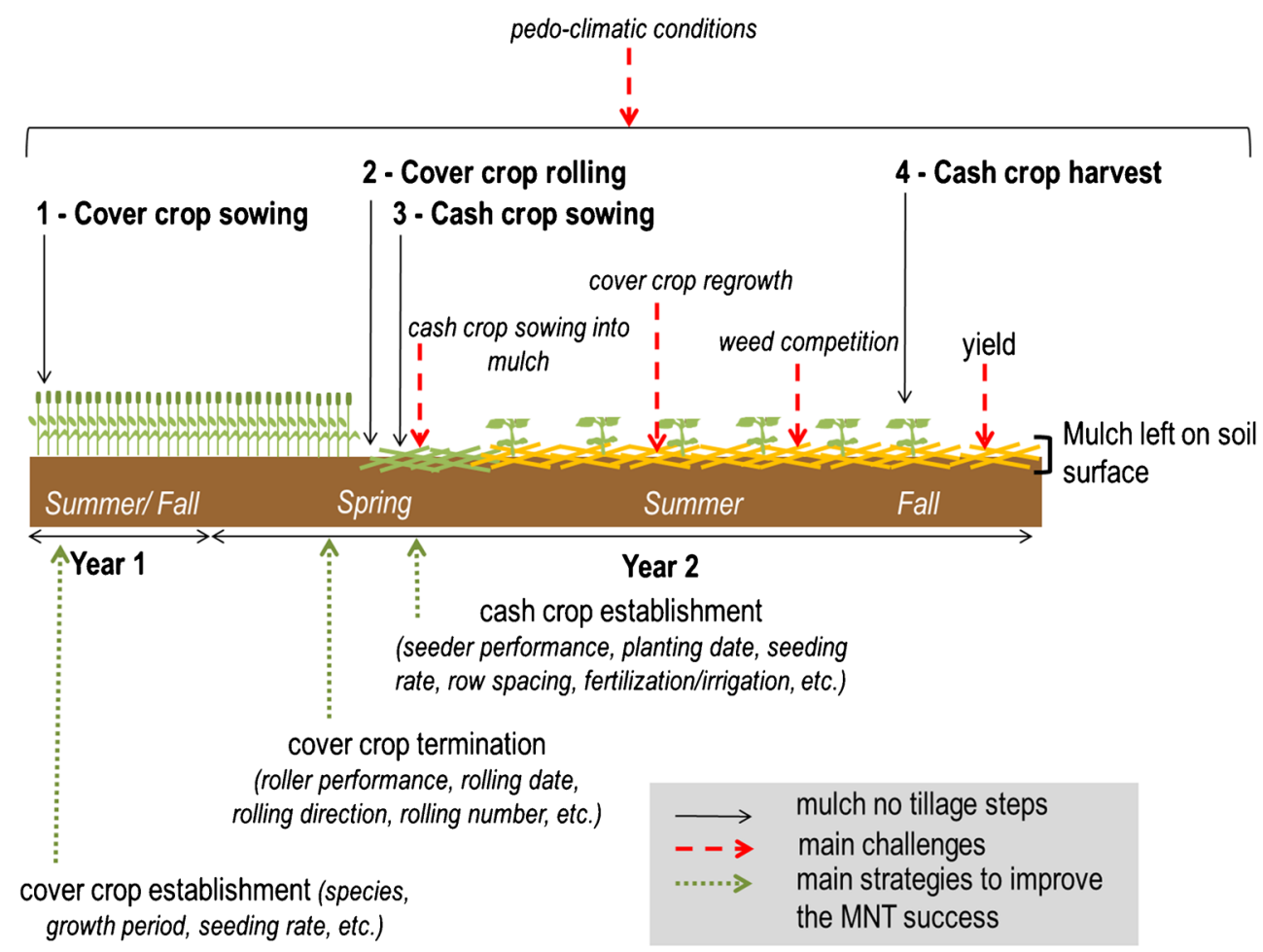


Table 1 Effect of cover crops tested in organic soybean and maize mulch-based no tillage system

\begin{tabular}{|c|c|c|c|c|}
\hline Cover crop & Advantages & Drawbacks & Location & References \\
\hline $\begin{array}{l}\text { Pure winter grain } \\
\text { cover crop } \\
\text { (cereal rye, } \\
\text { triticale, oat, } \\
\text { barley) }\end{array}$ & $\begin{array}{l}\text { Allelopathic effect, } \mathrm{N} \\
\text { immobilization, } \\
\text { high C/N ratio, high biomass } \\
\text { production, } \\
\text { height specie, slow decay, } \\
\text { terminated by } \\
\text { rolling, early flowering, } \\
\text { sowing date } \\
\text { flexibility, low sensibility to } \\
\text { pest }\end{array}$ & $\begin{array}{l}\text { N immobilization, } \\
\text { substantial needs } \\
\text { of water and nutrients } \\
\text { resources, } \\
\text { slow N release }\end{array}$ & $\begin{array}{l}\text {-North America (Iowa, } \\
\text { Pennsylvania, } \\
\text { Wisconsin, North } \\
\text { Carolina, } \\
\text { Quebec) } \\
\text {-South America (Brazil) } \\
\text {-Europe (southern France) }\end{array}$ & $\begin{array}{l}\text { (Altieri et al. 2008; Clark et al. } \\
\text { 2017; } \\
\text { Delate et al. 2012a, b; } \\
\text { Lefebvre et al. } \\
\text { 2011; Liebert et al. 2017; } \\
\text { Mirsky et al. } \\
\text { 2012; Peigné et al. 2015; } \\
\text { Silva 2014; } \\
\text { Wallace et al. 2017; Wells } \\
\text { et al. 2015; } \\
\text { Zinati et al. 2017) }\end{array}$ \\
\hline $\begin{array}{l}\text { Species mixture } \\
\text { (cereal rye/ } \\
\text { barley; cereal } \\
\text { rye/hairy } \\
\text { vetch; } \\
\text { wheat/Austrian } \\
\text { pea, hairy } \\
\text { vetch/triticale) }\end{array}$ & $\begin{array}{l}\text { High biomass production, high } \\
\mathrm{C} / \mathrm{N} \\
\text { ratio than pure legume, } \\
\text { compromise } \\
\text { between } \mathrm{N} \text { release and residue } \\
\text { persistence }\end{array}$ & $\begin{array}{l}\text { Slow } \mathrm{N} \text { release, lower } \\
\text { biomass than } \\
\text { pure rye, } \mathrm{N} \text { provisioning } \\
\text { reduced } \\
\text { by high } \mathrm{N} \text { immobilization } \\
\text { by } \\
\text { microorganisms during } \\
\text { rye decay, } \\
\text { more difficulties in } \\
\text { terminating } \\
\text { cover with several species }\end{array}$ & $\begin{array}{l}\text {-North America (New York) } \\
\text {-North America (Iowa) } \\
\text {-South America (Brazil) }\end{array}$ & $\begin{array}{l}\text { (Altieri et al. 2008; Delate et al. } \\
\text { 2012a, b; } \\
\text { Keene et al. 2017; Liebert } \\
\text { et al. 2017) }\end{array}$ \\
\hline $\begin{array}{l}\text { Pure legume cover } \\
\text { crop } \\
\text { (hairy vetch, } \\
\text { Austrian } \\
\text { winter pea) }\end{array}$ & $\begin{array}{l}\text { Higher } \mathrm{N} \text { production and } \\
\text { restitution, } \\
\text { high biomass production } \\
\text { compared } \\
\text { with other legumes }\end{array}$ & $\begin{array}{l}\text { Fast decay, excellent } \\
\text { termination by } \\
\text { rolling at early pod set } \\
\text { stage, lower } \\
\text { biomass than grain species }\end{array}$ & $\begin{array}{l}\text {-North America (Iowa, } \\
\text { Wisconsin) }\end{array}$ & $\begin{array}{l}\text { (Delate et al. 2012a, b; Silva } \\
\text { 2014; } \\
\text { Parr et al. 2011) }\end{array}$ \\
\hline
\end{tabular}

throughout the cash crop season, synchronicity of cover crop maturity for termination and cash crop planting dates, and resistance pests and diseases that could affect cash crops (Mischler et al. 2010a; Mirsky et al. 2012).

In MNT soybean production, small grain species (e.g., cereal rye, barley (Hordeum vulgare L.), triticale (x Triticosecale Wittmack), and oats (Avena sativa L.)) have been most extensively studied (Table 1). These species produce high amounts of biomass at the time of termination, with higher carbon-tonitrogen $(\mathrm{C}: \mathrm{N})$ ratios which slow residue decay (Mirsky et al. 2012) and provide persistent soil coverage for weed suppression throughout the season. Cereal rye is the most common small grain cover crop evaluated for soybean MNT, as it is easily integrated into typical organic crop rotations with planting after the crop harvest in late summer or early fall, while providing the advantages of winter hardiness, high biomass, and consistent weed suppression (Smith et al. 2011; Clark et al. 2017). Cereal rye provides further benefits compared with other small grains including faster emergence, greater allelopathic effects, earlier flowering, and consistent cover crop termination by rolling-crimping, as well as producing the highest soybean yields across a variety of pedo-climatic conditions (Liebert et al. 2017; Silva and Delate 2017; Wallace et al. 2017; Vincent-Caboud et al. 2019) (Table 1). Beyond the physical impedance provided by the mulch, decomposition of cereal rye mulch can result in $\mathrm{N}$ immobilization, which further inhibits the germination and development of weeds (Mohler et Callaway 1995; Reberg-Horton et al. 2012).

In MNT organic maize production, several legume cover crop species have been studied which can supply a portion of the N requirements for maize (Table 1) (Mischler et al. 2010b; Parr et al. 2011). These legume cover crops include hairy vetch, winter pea, and crimson clover (Trifolium incarnatum L.). Hairy vetch has been the most frequently studied, as it can produce high levels of biomass and substantial $\mathrm{N}$ compared to other legume species and is winter-hardy across a wide range of geographic regions (Mirsky et al. 2012). Hairy vetch typically produces from 4900 to $6000 \mathrm{~kg} \mathrm{ha}^{-1}$ of biomass, providing 140 to $225 \mathrm{~kg} \mathrm{~N} \mathrm{ha}^{-1}$, which could theoretically meet the maize requirements for $\mathrm{N}$ (Table 1) (Mirsky et al. 2017). As such, hairy vetch has resulted in the highest maize yields among the cover crop screened (Table 2) (Parr et al. 2011). Species such as crimson clover, although able to provide substantial $\mathrm{N}$ credits when plowed under, are not adapted to organic MNT due to low biomass production leading to weed development (Parr et al. 2011; Peigné et al. 2015). While some studies focused on MNT maize production have included cereal grains either in a monoculture of in a mixture with a 
Table 2 Effect of different cash crop sowing periods in mulch no tillage production

\begin{tabular}{|c|c|c|c|}
\hline Cash crop sowing period & Advantages & Drawbacks/difficulties & References \\
\hline $\begin{array}{l}\text { Seeding } 1-2 \text { weeks } \\
\text { after rolling }\end{array}$ & $\begin{array}{l}\mathrm{N} \text { supply, soil warming, second } \\
\text { rolling possible }\end{array}$ & $\begin{array}{l}\text { Cover crop regrowth, risk of weed } \\
\text { emergence before the main crop } \\
\text { sowing, technical problems with } \\
\text { sowing into flattened cover crop } \\
\text { (soil-seed contact), shorter cover } \\
\text { crop growth season }\end{array}$ & $\begin{array}{l}\text { (Delate et al. 2012a, b; Mirsky et al. } \\
\text { 2012; Reberg-Horton et al. 2012; } \\
\text { Bernstein et al. 2011) }\end{array}$ \\
\hline $\begin{array}{l}\text { Seeding same day } \\
\text { of rolling }\end{array}$ & $\begin{array}{l}\text { Minimal soil disturbance: rolling } \\
\text { and sowing operation combination } \\
\text { possible (fuel and labor savings), } \\
\text { longer cover crop growth season, } \\
\text { sowing into recent flattened cover } \\
\text { crop (fewer technical issues) }\end{array}$ & $\begin{array}{l}\text { Technical problems with seeding into } \\
\text { thick mulch (seed-soil contact), } \\
\text { low N released, lower soil } \\
\text { temperature }\end{array}$ & \\
\hline $\begin{array}{l}\text { Seeding before the } \\
\text { cover crop rolling }\end{array}$ & $\begin{array}{l}\text { Potential lower hair-pinning problem, } \\
\text { potential better soil-seed contact, } \\
\text { greater yield potential from longer } \\
\text { cash crop growing season }\end{array}$ & $\begin{array}{l}\text { Technical problems related to cover } \\
\text { crop height, lack of reference }\end{array}$ & \\
\hline
\end{tabular}

legume cover crop, the inclusion of cereal grains can increase $\mathrm{N}$ immobilization and increase insect pest issues, including true armyworm (Pseudaletia unipuncta), black cutworm (Agrotis ipsilon), and seed maize maggot (Delia platura) (Dunbar et al. 2016).

Research has also been conducted on mixtures of cover crop species in MNT which can provide benefits for weed suppression and hasten canopy cover prior to termination (Table 1) (Liebert et al. 2017). For instance, cereal rye combined with other species (e.g., triticale and barley) characterized by shorter height and wider leaves could increase light interception and shading. However, the use of multi-species mixtures can create additional management challenges due to the absence of synchronized maturity across species (Moyer 2011).

Cereal and legume mixtures can provide benefits to weed control and foster a balance between $\mathrm{N}$ availability, $\mathrm{N}$ immobilization, and cover crop decomposition (Altieri et al. 2008; Delate et al. 2012a, b). Pure legume cover crops are characterized by a low C:N ratio (e.g., C:N of 11 for hairy vetch), which can lead to rapid residue decay, limiting the ability of mulch to ensure adequate weed suppression (Reberg-Horton et al. 2012). Legume/cereal grain mixtures can offer advantages in maize MNT systems by increasing the $\mathrm{C}: \mathrm{N}$ ratio of the cover crop mulch, thus improving both the $\mathrm{N}$ availability and the mulch persistence on the soil surface (Parr et al. 2011). Across cereal grain/legume mixtures tested, the cereal rye/vetch mixture showed greater benefits with respect to soil fertility and beneficial insect populations compared with a winter wheat/Austrian winter pea (Pisum sativum L.) mixture (Delate et al. 2012a, b).

\subsubsection{Cover crop seeding}

As referenced above, a large component of MNT success lies in the production of adequate cover crop biomass at termination, which has been estimated at 8000 to $9000 \mathrm{~kg} \mathrm{ha}^{-1}$ of dry cover crop biomass. Cover crop seeding date and rates have been shown to have a profound impact on cover crop biomass and weed suppression (Ryan et al. 2011; Reberg-Horton et al. 2012; Hayden et al. 2014). Studies also showed that earlier cover crop sowing during the late summer/early fall planting windows can increase cover crop biomass production, thereby enhancing weed control (Mirsky et al. 2013; Moyer 2011). Similarly, the seeding rate of the cover crop influences final biomass which in turn decreases the potential for weeds to establish. Ryan et al. (2011) reported that 10 days after cover crop termination, a $31 \%$ decrease of weed density occurred with an increase in the cereal rye seeding rate from 90 to $210 \mathrm{~kg} \mathrm{ha}^{-1}(p=0.018)$. A similar conclusion was obtained with hairy vetch (Mirsky et al. 2017). The combination of a high seeding rate and an early planting with adequate fertility reduces weed establishment due to greater soil coverage both prior and subsequent to cover crop termination (Boyd et al. 2009; Brennan et al. 2009).

Seedbed preparation at cover crop planting can also impact the success of MNT systems. While tillage is eliminated with MNT during cash crop development, cover crop seeding is often performed in organic farming after soil tillage to manage existing perennial weeds and to allow for rapid cover emergence as soil temperatures begin to cool in the fall (Mirsky et al. 2013). A false seedbed before seeding the cover crop can further reduce weed populations by lowering the weed seedbank and preventing early emerging weeds from establishing through the mulch (Ryan et al. 2011).

\subsubsection{Cover crop termination}

As synthetic chemicals are prohibited in OF, termination typically relies on mechanical methods with a roller-crimper, mower, or chopper machine. Decisions on the cover crop control method should consider (1) sustained persistence of the mulch on the soil surface to maintain weed suppression, (2) 
labor and fuel used requirements, and (3) level of soil disturbance.

Effect of cover crop maturity on termination efficacy To successfully terminate a cover crop without herbicides, the cover crop must be an annual species and reach the appropriate growth stage (Ashford and Wayne Reeves 2003). Typically, cover termination is improved by delaying until the reproductive stage (i.e., flowering stage) (Parr et al. 2014; Wells et al. 2014, 2015). Cover crop termination at $80-100 \%$ flowering for winter annual cereal species has been reported to be most effective, with termination becoming increasingly effective as the cover crop matures to the soft dough stage (Moyer 2011). Winter annual legume species similarly must reach appropriate physiological maturity, with termination most effective when a minimum of $75 \%$ of plants have reached the end of the flowering or early pod stage (Cook et al. 2010; Légère et al. 2012). Mischler et al. (2010b) demonstrated excellent hairy vetch control with termination at the late pod stage compared to termination at less than $80 \%$ flowering because of a shorter height than winter cereal species and stems climbing and branching. Yield losses in maize are often attributed to insufficient termination of the cover crop, with hairy vetch regrowing during the cash crop establishment (Keene et al. 2017; Wallace et al. 2017). Additionally, soil N deficiency can result due to lack of synchronization between $\mathrm{N}$ release from the cover crop and cash crop $\mathrm{N}$ needs (Parr et al. 2014). These issues with using hairy vetch as the cover crop in maize MNT have contributed to the significant yield losses documented in many regions including Iowa (USA) and France (Delate et al. 2012a, b; Peigné et al. 2015).

A longer period of cover crop growth results in a greater cover crop biomass, leading to thicker and more persistent mulch layers for effective weed suppression (Hartwig and Ammon 2002). However, synchronizing crop seeding with the appropriate stage of cover crop termination can result in delayed planting dates, compromising crop yields (Carr et al. 2013; Davis 2010). For example, in Pennsylvania, the pod set growth stage of hairy vetch occurs 4 to 6 weeks after the typical maize planting dates (Mischler et al. 2010b). Mirsky et al. (2012) suggested developing earlier-maturing cover crop cultivars adapted for rolling when maize is typically planted.

Mechanical strategies for cover crop termination In organic MNT systems, mechanical strategies are the primary method of cover crop termination. Several techniques have been assessed, including types of roller-crimpers, sickle bar mowers, and flail choppers (Kornecki et al. 2010; Reberg-Horton et al. 2012).

Mowing has been evaluated for MNT, as many types of mowing and chopping equipment are available on farms (Smith et al. 2011; Vaisman et al. 2011). However, the smaller cover crop fragments created by the chopper accelerate residue decay, resulting in limited soil cover (Creamer and Dabney 2002). The flail chopper can also lead to an uneven distribution of mulch on the soil surface, allowing weeds to emerge. Compared to the flail chopper, the sickle bar mower minimizes these issues by creating a mulch of intact cereal grain stems laid down in a parallel arrangement, increasing persistence and easier planting through the residue (Smith et al. 2011). However, the sickle bar mower does not perform well in the termination of legume species due to cover crop entanglement with the cutter blade.

The roller-crimper, which originated in Brazil, has emerged as a particularly promising tool for organic MNT (Ashford and Wayne Reeves 2003; Mirsky et al. 2011). The roller-crimper crushes the stems of plants, damaging the vascular tissues without cutting the stems, thereby inhibiting the continued growth of the crop. Because the cover crop is anchored to the soil by the root, there is less potential for raking and dragging of the mulch when planting as well as movement of the mulch by wind and water later in the season. The maintenance of intact cover crop residue ensures longer mulch persistence, thereby improving weed control (Mirsky et al. 2012; Liebert et al. 2017). The roller-crimper also provides a more uniform mulch distribution and requires less labor and fuel compared to mowing (Mischler et al. 2010b; Mirsky et al. 2012). Greater weed suppression after cover crop termination with the roller-crimper compared with other mechanical strategies (i.e., a mower, sickle bar mower, and/or flail mower) was reported (Smith et al. 2011; Silva 2014).

Roller-crimpers for MNT are being developed with a wide variety of designs and widths (Kornecki et al. 2006, 2009), with sizes varying from 2- to 6-m wide. However, the availability of this equipment is limited in Europe, creating a barrier for development and limiting options for cover crop management (Soane et al. 2012). Thus, farmers and researchers are compelled to build their own equipment, requiring skill in the design and fabrication of rollers adapted to MNT principles (e.g., minimal soil disturbance and damaging the cover crop without cutting the stems) (Peigné et al. 2015).

Improvements in roller-crimper performance have been proposed to increase the success of MNT based on equipment changes and the technical skills of the operator. The USDAARS has provided technical information comparing the effects of several roller designs on cover crop control, equipment vibration, rolling speed, and soil covering (Kornecki et al. 2010, 2012). The results showed that certain roller designs led to less vibration with higher rolling speeds; the excessive vibration associated with the first-generation designs of rollers had decreased their adoption. While reducing rolling speed can mitigate vibrations, a slower roller increases labor hours, which is also a concern for farmers. Roller-crimper blades arranged in a chevron pattern on the cylinder reduce vibrations (Kornecki et al. 2005).

Minor technical and agronomic changes can enhance the efficacy of the roller-crimper. Additional weight may be added on the roller-crimper, with some designs allowing the rollercrimper to be filled with water (Delate et al. 2012a, b). The 
direction of rolling can impact termination efficacy, with crimping at a diagonal angle $\left(45^{\circ}\right)$ or at an angle of $90^{\circ}$ to the seeding direction of cover crop resulting mulch distribution (Kornecki et al. 2005; Mirsky et al. 2012) (Fig. 4). To improve and speed up the cover crop termination after cover crop rolling, Frasconi et al. (2019) use a flame weeder after cover crop rolling. Flame weeders were also tested by other researchers as an alternative option to manage weeds in organic MNT production system but they explained that further studies are needed to optimize the economic benefits regarding to the high operational cost required (Landers et al. 2016; Frasconi et al. 2019; Bavougian et al. 2019).

\subsection{Cash crop production}

While the cover crop management factors related to the establishment of a thick persistent mulch are key aspects of MNT success, cash crop establishment is equally important. The presence of the mulch at cash crop planting can lead to several challenges, including cooler soil temperatures, excessively wet or dry soil moisture conditions, poor seed-to-soil contact, and difficulty applying starter fertilizers.

Obtaining target plant populations can be difficult in MNT. Recent studies have shown that higher soybean planting rates, compared to the standard regional recommendation, result in not only greater plant populations and yields, but also expedite soybean canopy closure resulting in greater weed suppression (Place et al. 2009; Liebert and Ryan 2017; Liebert et al. 2017). For example, in North Carolina (USA), researchers testing a range of planting rates to a maximum of 740,000 seeds ha found that increasing the standard soybean seeding rate by nearly $50 \%$ increased yields by approximately $15 \%$ with less weed pressure (Place et al. 2009). Increasing cash crop seeding rates can be particularly important to compensate when cover crop biomass is low (i.e., $<8000 \mathrm{~kg} \mathrm{ha}^{-1}$ ) (Ryan et al. 2011).

Appropriate equipment for cash crop planting into the cover crop mulch is essential for the success of MNT systems (Wallace et al. 2017). A number of equipment companies manufacture heavy duty planters that are appropriate for
MNT (Delate et al. 2012a, b; Moyer 2011). Poor seed-to-soil contact may occur at planting due to the thick mulch layer on the soil surface (e.g., "hair-pinning" of the cover crop) and can impair seed placement at the 3 to $4 \mathrm{~cm}$ depth (Peigné et al. 2015). Thus, planter adjustments (e.g., addition of weight and row cleaners) are recommended for optimizing the performance of NT planters (Clark et al. 2017). Row cleaners have been adapted to planters used in the USA for organic MNT, assisting in the slicing of residues on the seeding row and improving seed placement and crop emergence through the mulch (Reberg-Horton et al. 2012). Additional weight on the unit planter can also improve seed-soil contact, with removal of coulters further increasing the overall weight on each individual planter unit (Moyer 2011; Clark et al. 2017).

The cooler soil temperatures present under the thick mulch layer can hinder cash crop establishment as well (Soane et al. 2012; Halde 2014; Mirsky et al. 2012; Dabney et al. 2001). This delay in cash crop growth can persist for a prolonged period, delaying canopy closure and allowing weeds to establish. Narrow row spacing has been proposed as a strategy for enhancing early soybean canopy closure (Bernstein et al. 2011; Lefebvre et al. 2011). Lefebvre et al. (2011) obtained improved soybean stand establishment but also soybean lodging with narrow row spacing (i.e., $2.10 \mathrm{t} \mathrm{ha}^{-1}$ with $38 \mathrm{~cm}$ ) compared with 76-cm row spacing conducting to $1.84 \mathrm{t}$ $\mathrm{ha}^{-1}$. Further research is needed, however, to understand the impact of narrow row spacing on yield and quality, particularly related to pest pressure and lodging.

\subsection{Nutrient and water management}

\subsubsection{Soil fertility and nutrient management}

Changes in the chemical, physical, and biological properties of soil have been reported with the use of organic MNT. Vian et al. (2009) and Peigné et al. (2009) reported an improvement of soil health indicators, with a greater abundance of earthworms and a higher organic carbon, $\mathrm{N}$ mineralization and microbial carbon concentration at 0-30 cm depth compared with traditional plowing. In conventional production systems,

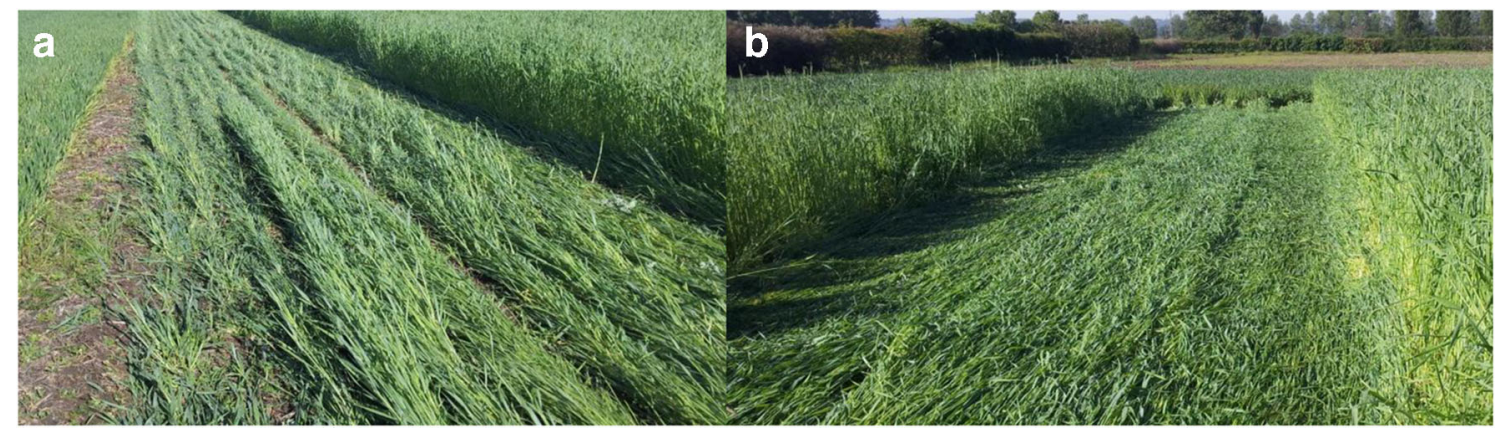

Fig. 4 a Illustration of cover crop control after rolling was performed in a similar direction to the cover crop sowing, b illustration of cover crop management after rolling was carried out in a perpendicular direction to the cover crop sowing. (pictures L. Vincent-Caboud) 
long-term studies have shown increased microbial biomass, soil N, and organic carbon storage with winter cover crop use (García-González et al. 2018; Liu et al. 2005; Ding et al. 2006; Motta et al. 2007; Blanchart et al. 2007). Cover crop were also shown to have potential to improve water quality because of decreased $\mathrm{NO}_{3}{ }^{-}$leaching (Qi and Helmers 2010; Dabney et al. 2001; Villamil et al. 2006). However, long-term research is needed in organic MNT systems to determine if results are similar to what has been observed in conventional systems.

Research has also shown that mulch on the soil surface change the mineralization dynamics and can have negative impacts on $\mathrm{N}$ availability for the cash crop (Bernstein et al. 2011; Halde et al. 2014). For example, Bernstein et al. (2011) reported that the tissue $\mathrm{N}$ concentration of soybean grown under mowed rye was significantly lower than plowed soybean (i.e., respectively $41 \mathrm{~g} \mathrm{~kg}^{-1}$ and $49 \mathrm{~g} \mathrm{~kg}^{-1}$ ), potentially due to nutrient tieup related to decomposition of the cereal rye mulch.

The importance of developing fertility management strategies in MNT is an emerging theme in research community. According to Clark et al. (2017), soil fertility is fundamental for supporting cover crop development and maintaining yields in MNT. With the cover crop remaining physiologically active for 3-6 weeks after rolling, solutions to manage cover crop competition with the cash crop at emergence must be considered (Delate et al. 2012a, b; Légère et al. 2012). Delate et al. (2012a, b) argued that the cover crop cannot be relied upon as the sole source of $\mathrm{N}$ for cash crops with high $\mathrm{N}$ needs such as maize. At the Rodale Institute in Pennsylvania, a high maize yield was obtained with sufficient $\mathrm{N}$ provided from compost that was applied before seeding hairy vetch in the fall in addition to the $\mathrm{N}$ from the rolled hairy vetch (Vann et al. 2017). Mirsky et al. (2012) suggested that a high rate of fertilizer applied to the planting row could support emergence and early growth of the cash crop. Fertility management can also contribute to ensuring adequate cover crop biomass. Ryan (2010) reported an increase in cereal rye biomass with the highest fertilizer rate applied in spring to cereal rye; however, the increased cover crop biomass did not translate into improved weed suppression.

\subsubsection{Water and temperature conditions under mulch-based no tillage systems}

The effect of MNT on soil moisture conservation and related water requirements remains unclear and is climate-dependent. Understanding these dynamics is essential for developing best management practices for establishing cash crops using NT (Pittelkow et al. 2015). In Wisconsin, a more humid climate, a greater conservation of soil water content was reported in MNT throughout the cash crop production season (Silva 2014; Lefebvre et al. 2011). However, in Canada, a lower soil water content was reported under cereal rye mulch, as the cover crop likely consumed significant water from the soil profile prior to termination (Lefebvre et al. 2011). In conventional production, researchers have observed that the depletion of soil water due transpiration from cover crops was offset by a lower soil water evaporation during the cash crop season (Qi and Helmers 2010; Duval et al. 2016). Moisture retention from mulch could be an important benefit in regions where short-term droughts during the midsummer are projected to increase in frequency (Basche et al. 2016). Cover crop species also affects the soil water content. For example, greater soil moisture was reported under mulch from legume species compared with mulch from winter annual grain species (Silva 2014). In situations where the option is available, irrigation can be applied to offset any deficits created through transpiration from the cover crop (Delate et al. 2012a, b).

Lower soil temperatures in MNT can affect weed growth, but also hinder the germination and emergence of cash crops, particularly those planted earlier in the spring (Soane et al. 2012; Halde et al. 2014). Teasdale and Mohler (1993) indicate that soil temperature was $3{ }^{\circ} \mathrm{C}$ lower under cover crop than control treatment without cover crop. The authors explain that this temperature difference did not reduce weed emergence but delayed their development compared with the tillage plots. Regarding slower soil warming in MNT system compared with traditional practices without cover crop, delaying cash crop seeding resulted in planting into warmer soil, which hastened crop seedling emergence and limited pest insect damage at emergence. However, this change in cash crop planting date must be considered in tandem with the general optimization of crop management (Mirsky et al. 2012; Delate et al. 2012a, b; Moyer 2011) (Table 2).

Despite some scattered references on nutrient and water management in organic MNT, the physical properties of soil in such systems have not yet been documented due to the short-term trials carried out with this technique. In conventional system production, researchers have shown that cover crop-based production systems improve soil aggregate due to higher binding agents (e.g., polysaccharides, water extractable carbohydrates) (Lal 2015; Liu et al. 2005). Further studies are required under long-term organic MNT systems to better understanding the specific changes on to soil properties.

\subsection{Economic performance and social benefits}

Although few references exist, several researchers have highlighted the economic and social benefits conferred through MNT systems (Bernstein et al. 2011; Delate et al. 2012a, b; Singh et al. 2018). Economic benefits have been documented in the USA and Canada as a result of fewer field operations, resulting in decreased fuel, energy use, and labor costs (Moyer 2011; Silva and Delate 2017). Consequently, despite slightly reduced yields in MNT soybean, the return per ha is $25 \%$ greater in organic MNT compared to typical 
organic practices (Bernstein et al. 2011). Furthermore, MNT can improve the quality of life for farmers, reducing labor requirements, which allow for additional time to engage in other on- and off-farm activities that can improve overall gross margins. Fuel costs in organic MNT can be reduced by $50 \%$ compared with typical organic practices (Moyer 2011). Delate et al. $(2012 \mathrm{a}, \mathrm{b})$ found that MNT practices resulted in a $65 \%$ decrease in production costs compared to typical organic management; however, these Iowa-based trials also highlighted that the resulting yields greatly impacted the return to management for farmers. For example, the return to management was reduced by $93 \%$ in MNT for maize and by $67 \%$ for soybean compared to typical organic practices, in part, due to cover crop competition with the main crop under low precipitation. Long-term studies are needed to create reliable economic assessments at crop rotation levels that consider system-wide impacts on soil fertility and weed seedbanks.

\section{Research agenda for the future}

Current research demonstrates the potential of MNT as an organic management tool and highlights areas that could lead to significant advancements in the success and adoption of the organic MNT. The following sections discuss these ongoing challenges and future directions.

\subsection{Optimizing organic cash crop planting}

While cash crop planting in MNT typically occurs at cover crop termination, other timing strategies for cash crop planting and cover crop termination have recently emerged. Table 2 and Fig. 5 describe three practices for cash crop sowing according to cover crop rolling time: (1) cash crops are typically sown the same day as cover crop termination with a tractormounted roller-crimper (Delate et al. 2012a, b) (Fig. 5a); (2) cash crop seeding several days or weeks after rolling the cover crop at anthesis, fostering quicker cash crop emergence due to warmer soil, and synchronization with the beginning of $\mathrm{N}$ release from mulch decay (Fig. 5b) (Liebert et al. 2017); and (3) cash crop seeding prior to cover crop termination, overcoming difficulties faced when seeds are sown into the biomass, and thereby improving seed-soil contact (Fig. 5c) (Porter et al. 2005; Bernstein et al. 2011). More research are needed to clarify the best combination of cash crop planting and cover crop termination practices across geographic regions and climatic conditions.

\subsection{Cash crop variety selection and breeding for adaptation to organic mulch-based no tillage}

There is limited information on the impact of cash crop cultivars on MNT success. In Canada, Lefebvre et al. (2011) compared three cultivars of soybean with early, mid-late, and late maturity traits. Although weed biomass did not differ, higher soybean yield was obtained with the mid-late-maturing cultivar (i.e., $2.23 \mathrm{t} \mathrm{ha}^{-1}$ ) compared with the early-maturing cultivar (i.e., $1.88 \mathrm{t} \mathrm{ha}^{-1}$ ).

Further breeding and screening efforts could be increased to develop cash crop cultivars that are better adapted to MNT in OF. More competitive cultivars with greater $\mathrm{N}$ efficiency could contribute to the mitigation of the issue of $\mathrm{N}$ immobilization in the system. Cultivars adapted to the challenges related to germination and stand establishment, including poor
Fig. 5 Schema representing methods of cash crop sowing using an organic mulch no tillage

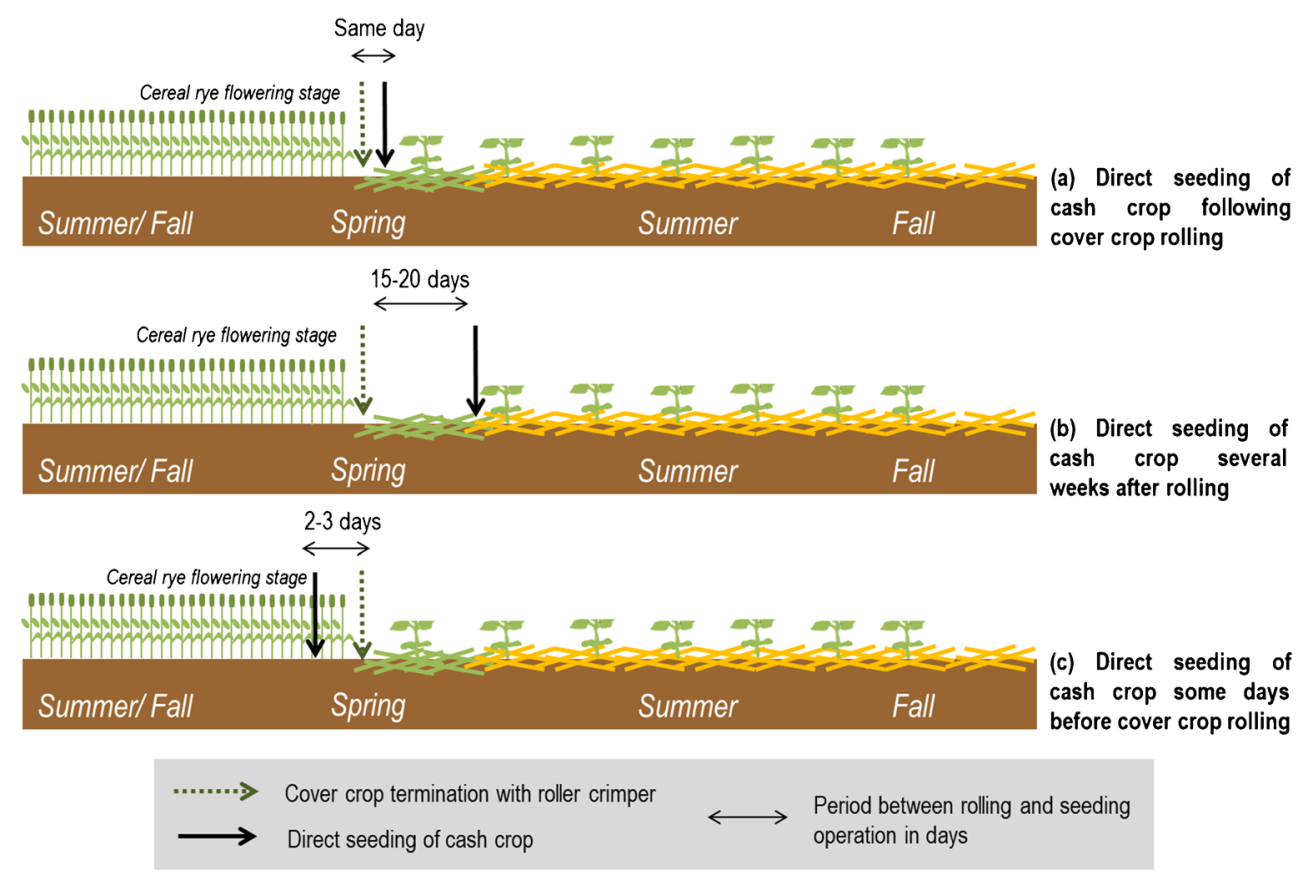


seeding conditions, cool soil temperatures, and emergence through the thick mulch, could provide significant benefits. Finally, early-maturing cultivars could help mitigate the issues with delayed cash crop planting caused by the need to synchronize seeding with the mechanical management of the cover crop. The seeding of Flex-Ear maize in MNT systems can be conducive to very good performance in both high and low populations.

\subsection{Optimizing cover crop/cash crop combinations}

Optimizing cover crop mixture and cover crop/cash crop combinations remains a major challenge in organic MNT success (Moyer 2011; Halde et al. 2017). Further research must be conducted to document the performance of cover crop mixture with respect to weed suppression and cover crop control under a wide diversity of temperate soil and climate. Many questions remain on the selection of the best cover crops for non-legume cash crop organic MNT production, where yields have been documented to be extremely variable (Mischler et al. 2010b; Peigné et al. 2015). Compromises must be developed between two conflicting production goals: (1) increased C:N ratio of cover crop to manage weeds and (2) decreased C:N ratio to provide sufficient $\mathrm{N}$ availability ensuring the needs of the cash crop (Williams et al. 2018; Liebman et al. 2018). Further research is needed to optimize mechanical termination with diverse species that have different phenologies (Moyer 2011; Wallace et al. 2017; Tosti et al. 2012; Halde and Entz 2016; Jani et al. 2016).

Additionally, studies are required to screen a range of both pure stands and mixtures of cover crop under various pedoclimatic conditions to provide more flexible decision support tools. As a result of this review, six primary factors can be incorporated into a decision support tool related to both cover crop and cash crop management in organic MNT: (i) critical cover crop biomass and height, (ii) appropriate $\mathrm{C}: \mathrm{N}$ ratio, (iii) estimation of mulch decay rates, (iv) efficiency of cover crop termination, (v) cover crop maturity dates, and (vi) competition for and/or provision of nutrients and water resources with cash crops.

\subsection{Roller-crimper and mulch-based no tillage planting equipment}

While effective equipment has been designed for cover crop control, less emphasis has been placed on the modification of traditional NT equipment to allow the planter to perform in thick mulch (Kornecki et al. 2005; Kornecki et al. 2010; Reberg-Horton et al. 2012). Gaps in access, skills, and knowledge regarding both roller-crimper and MNT planter optimization limit the success of MNT and its wide acceptance. Additional equipment and strategies should be identified to provide solutions to manage weeds and improve cover crop control while ensuring seed placement through the mulch
(Zinati et al. 2017). However, as with the integration of any new tools, their impact on the goals of MNT (e.g., soil quality, fuel, energy, and labor savings) must be considered. The inclusion of a diversity of regional stakeholders in a participatory research process would be a solution to provide appropriate equipment specific to the local conditions (e.g., farmers, manufacturers, and researchers).

In addition to planting equipment, researchers should consider different tools that can be used to control weeds after cash crops are planted in the MNT system. High-residue cultivation could be used for supplemental weed control in organic MNT soybean and maize production (Zinati et al. 2017). For example, crop yields increased by up to $35 \%$ when a multi-tactic weed management approach was used that included high-residue cultivation and hand weeding (Zinati et al. 2017). Another option being explored for between-row weed management includes inter-row mowing equipment that could limit weed growth while avoiding soil disturbance.

\subsection{Redesigning the organic cropping system}

Implementing technical solutions requires substantial changes at several levels (e.g., altering planting dates at the field scale, designing crop rotations at the cropping system scale, prioritizing equipment at the farm scale) (Moyer 2011). Long-term research has recently begun in North America at the crop rotation scale, but this approach needs to be applied to other regions to consider the specific constraints of the current crop rotations practiced by local farmers and the diversity of farming systems encountered in specific regions (Teasdale et al. 2007; Anderson 2015; Wallace et al. 2018).

Research is needed on the effect of crop rotations for organic MNT and the impact of crop rotation on weed populations, weed communities, and crop yields. In some cases, crop rotations will need to be redesigned to accommodate early seeding of cover crops for the MNT system. To ensure alignment with farmers' objectives, a participatory approach is critical. Farmer-researcher partnerships create greater valorization of both scientific and local farmer knowledge and expedite the development of innovative and relevant solutions (Lefevre 2013). The development of sustainable cropping systems, including organic MNT, requires research and innovation across scales, including the field, cropping system, and farm.

\section{Conclusion}

MNT can provide a number of benefits in organic cropping systems, addressing agroecological (e.g., improving soil fertility, reducing soil erosion), economic (e.g., limiting fuel and energy consumption), and social concerns (e.g., reducing labor, improving well-being). In many regions, conditions required to optimize organic MNT performance remain poorly 
documented. The challenges that prevent expansion of organic MNT are related to the lack of knowledge and inclusion of strategies that work within farm constraints. In particular, a large knowledge gap exists with respect to soil changes (biological, chemical, and physical properties) in organic MNT systems due, in large part, to the lack of long-term studies. Identification of the best cover crop/cash crop combinations remains a primary bottleneck that must be addressed to ensure weed suppression while maintaining crop yields, particularly as related to local environments. The combination of a cereal rye cover crop/soybean cash crop has produced consistently positive results; however, in organic MNT maize production, the choice of cover crop species to allow for adequate planting dates, season-long weed suppression, and $\mathrm{N}$ availability remains a major challenge. The broader integration of MNT into organic cropping systems will require technical and social changes, including redesigning crop rotations and developing viable solutions with consideration of soil properties to address organic farmers' objectives and local constraints at the farm level.

Funding information The authors acknowledge the financial support for this project provided by transnational funding bodies, including partners of the FP7 ERA-net project, CORE Organic Plus, and cofunds from the European Commission, the TERRA ISARA foundation, the US Department of Agriculture, National Institute of Food and Agriculture, Organic Transitions Program (2014-51106-22080), and the French Water Agency "Rhône Méditerranée Corse." The text in this paper is the sole responsibility of the authors and does not necessarily reflect the views of the national and European funding bodies that financed this project.

\section{Compliance with ethical standards}

Conflict of interest The authors declare that they have no conflict of interest.

\section{References}

Altieri DM, Lovato DP, Lana MM, Bittencourt MH (2008) Testing and scaling-up agroecologically based organic conservation tillage systems for family farmers in southern Brazil. Presented at the 16th IFOAM Organic World Congress, Modena, Italy. http://orgprints. org/12338/. Accessed 23 January 2019

Altieri MA, Lana MA, Bittencourt HV, Kieling AS, Comin JJ, Lovato PE (2011) Enhancing crop productivity via weed suppression in organic no-till cropping systems in Santa Catarina, Brazil. J Sustain Agric 35(8):855-869. https://doi.org/10.1080/10440046.2011.588998

Anderson RL (2015) Integrating a complex rotation with no-till improves weed management in organic farming. A review. Agron Sustain Dev 35(3):967-974. https://doi.org/10.1007/s13593-015-0292-3

Ashford DL, Wayne Reeves D (2003) Use of a mechanical roller-crimper as an alternative kill method for cover crops. Am J Altern Agric 18(1):37-45. https://doi.org/10.1079/AJAA200232

Baker JC, Saxton KE (2007) No-Tillage Seeding in Conservation Agriculture. CABI

Basche AD, Kaspar TC, Archontoulis SV, Jaynes DB, Sauer TJ, Parkin TB, Miguez FE (2016) Soil water improvements with the long-term use of a winter rye cover crop. Agric Water Manag 172(July):40-50. https://doi.org/10.1016/j.agwat.2016.04.006

Bavougian CM, Sarno E, Knezevic S, Shapiro CA (2019) Cover crop species and termination method effects on organic maize and soybean. Biol Agric Hortic 35(1):1-20. https://doi.org/10.1080/ 01448765.2018.1455607

Beach HM, Laing KW, Van De Walle M, Martin RC (2018) The current state and future directions of organic no-till farming with cover crops in Canada, with case study support. Sustainability 10(2):373. https:// doi.org/10.3390/su10020373

Bernstein ER, Posner JL, Stoltenberg DE, Hedtcke JL (2011) Organically managed no-tillage rye-soybean systems: agronomic, economic, and environmental assessment. Agron J 103(4):1169. https://doi. org/10.2134/agronj2010.0498

Bilalis D, Karkanis A, Patsiali S, Agriogianni M, Konstantas A, Triantafyllidis V (2011) Performance of wheat varieties (Triticum aestivum L.) under conservation tillage practices in organic agriculture. Notulae Botanicae Horti Agrobotanici Cluj-Napoca 39(2):28. https://doi.org/10.15835/nbha3926228

Bilalis D, Karkanis A, Pantelia A, Patsiali S, Konstantas A, Efthimiadou A (2012) Weed populations are affected by tillage systems and fertilization practices in organic flax (Linum usitatissimum L.) Crop. Aust J Crop Sci 6(1):157. http://search.proquest.com/openview/ $7316879 \mathrm{c} 32197 \mathrm{a} 91 \mathrm{ec} 283 \mathrm{~b} 3366695 \mathrm{a} 3 \mathrm{a} / 1$ ?pq-origsite $=$ gscholar\&cbl=52462. Accesed 24 April 2018

Blanchart E, Bernoux M, Sarda X, Neto MS, Cerri CC, Piccolo M, Douzet J-M, Scopel E, Feller C (2007) Effect of direct seeding mulch-based systems on soil carbon storage and macrofauna in Central Brazil. Agric Conspec Sci 72(1):81-87. http://hrcak.srce. $\mathrm{hr} / 12906$. Accessed 18 May 2017

Boyd NS, Brennan EB, Smith RF, Yokota R (2009) Effect of seeding rate and planting arrangement on rye cover crop and weed growth. Agron J 101(1):47. https://doi.org/10.2134/agronj2008. 0059

Brennan EB, Boyd NS, Smith RF, Foster P (2009) Seeding rate and planting arrangement effects on growth and weed suppression of a legume-oat cover crop for organic vegetable systems. Agron J 101(4):979-988. https://doi.org/10.2134/agronj2008.0194x

Canali S, Diacono M, Campanelli G, Montemurro F (2015) Organic notill with roller crimpers: agro-ecosystem services and applications in organic Mediterranean vegetable productions. Sustain Agric Res 4(3):70. https://doi.org/10.5539/sar.v4n3p70

Carr P (2017) Guest editorial: conservation tillage for organic farming. Agriculture 7(3):19. https://doi.org/10.3390/agriculture7030019

Carr P, Gramig G, Liebig M (2013) Impacts of organic zero tillage systems on crops, weeds, and soil quality. Sustainability 5(7):31723201. https://doi.org/10.3390/su5073172

Casagrande M, Peigné J, Payet V, Mäder P, Sans FX, Blanco-Moreno JM, Antichi D, et al (2015) Organic farmers' motivations and challenges for adopting conservation agriculture in Europe. Org Agric, October, 1-15. https://doi.org/10.1007/s13165-015-0136-0.

Clark KM, Boardman DL, Staples JS, Easterby S, Reinbott TM, Kremer RJ, Kitchen NR, Veum KS (2017) Crop yield and soil organic carbon in conventional and no-till organic systems on a claypan soil. Agron J. https://doi.org/10.2134/agronj2016.06.0367

Cook JC, Gallagher RS, Kaye JP, Lynch J, Bradley B (2010) Optimizing vetch nitrogen production and corn nitrogen accumulation under notill management. Agron J 102(5):1491. https://doi.org/10.2134/ agronj2010.0165

Cooper J, Baranski M, Stewart G, Lange M N-d, Bàrberi P, Fließbach A, Peigné J et al (2016) Shallow non-inversion tillage in organic farming maintains crop yields and increases soil C stocks: a meta-analysis. Agron Sustain Dev 36(1). https://doi.org/10.1007/s13593-0160354-1 
Creamer NG, Dabney SM (2002) Killing cover crops mechanically: review of recent literature and assessment of new research results. Am J Altern Agric 17(1):32-40. https://doi.org/10.1079/AJAA20014

Crowley KA (2017) Tradeoffs in cereal rye management strategies prior to organic soybean. https://ecommons.cornell.edu/handle/1813/ 51549. Accessed 20 July 2017

Dabney SM, Delgado JA, Reeves DS (2001) Using winter cover crops to improve soil and water quality. https://doi.org/10.1081/CSS100104110

Davis AS (2010) Cover-crop roller-crimper contributes to weed management in no-till soybean. Weed Sci 58(3):300-309 http://www.jstor. org/stable/40891100. Accessed 28 March 2015

Delate K, Cwach D, Fiscus M (2012a) Evaluation of an organic no-till system for organic corn and soybean production-Agronomy Farm Trial, 2011. Organic Ag Program Webpage. Iowa State University, Ames http://extension.agron.iastate.edu/organicag/researchreports/ nk11notill.pdf. Accessed 3 August 2016

Delate K, Cwach D, Chase C (2012b) Organic no-tillage system effects on soybean, corn and irrigated tomato production and economic performance in Iowa, USA. Renewable Agric Food Syst 27(Special Issue 01):49-59. https://doi.org/10.1017/ S1742170511000524

Derpsch R (1998) Historical review of no-tillage cultivation of crops. In: FAO International Workshop, Conservation Tillage for Sustainable Agriculture, pp 205-218. http://www.rolf-derpsch.com/en/no-till/ historical-review/. Accessed 17 May 2016

Ding G, Liu X, Herbert S, Novak J, Amarasiriwardena D, Xing B (2006) Effect of cover crop management on soil organic matter. Geoderma 130(3):229-239. https://doi.org/10.1016/j.geoderma.2005.01.019

Dunbar MW, O'Neal ME, Gassmann AJ (2016) Increased risk of insect injury to corn following rye cover crop. J Econ Entomol 109(4): 1691-1697. https://doi.org/10.1093/jee/tow101

Duval ME, Galantini JA, Capurro JE, Martinez JM (2016) Winter cover crops in soybean monoculture: effects on soil organic carbon and its fractions. Soil Tillage Res 161(August):95-105. https://doi.org/10. 1016/j.still.2016.04.006

FAO (2011) 1. Introduction. http://www.fao.org/docrep/005/y2781f/ y2781f03.htm. Accessed 20 Feb 2017

Favarato LF, Galvão CC, Souza LJ, Guarçoni RC, Souza CM, Cunha DN (2014) Population density and weed infestation in organic no-tillage corn cropping system under different soil covers. Planta Daninha 32(4):739-746. https://doi.org/10.1590/S010083582014000400008

Frasconi C, Martelloni L, Antichi D, Raffaelli M, Fontanelli M, Peruzzi A, Benincasa P, Tosti G (2019) Combining roller crimpers and flaming for the termination of cover crops in herbicide-free no-till cropping systems. PLoS One 14(2):e0211573. https://doi.org/10. 1371/journal.pone. 0211573

García-González I, Hontoria C, Gabriel JL, Alonso-Ayuso M, Quemada M (2018) Data supporting the cover crops benefits related to soil functionality in a 10-year cropping system. Data Brief 18(June): 1327-1333. https://doi.org/10.1016/j.dib.2018.04.029

Halde C (2014) Organic rotational no-till system adapted for Manitoba, Canada. University of Manitoba. https://www.researchgate.net/ profile/Caroline_Halde/publication/264975100_Organic Rotational_No-Till_System_Adapted_for_Manitoba_Canada/links/ 53f904550cf2c9c3309e2df2.pdf. Accessed 20 February 2017

Halde C, Entz MH (2014) Flax (Linum Usitatissimum L.) production system performance under organic rotational no-till and two organic tilled systems in a cool subhumid continental climate. Soil Tillage Res 143(November):145-154. https://doi.org/10.1016/j.still.2014. 06.009

Halde C, Entz MH (2016) Plant species and mulch application rate affected decomposition of cover crop mulches used in organic rotational no-till systems. Can J Plant Sci 96(1):59-71. https://doi.org/ 10.1139/cjps-2015-0095
Halde C, Gulden RH, Entz MH (2014) Selecting cover crop mulches for organic rotational no-till systems in Manitoba, Canada. Agron J 106(4):1193. https://doi.org/10.2134/agronj13.0402

Halde C, Gagné S, Charles A, Lawley Y (2017) Organic no-till systems in eastern canada: a review. Agriculture 7(4):36. https://doi.org/10. 3390/agriculture7040036

Hartwig NL, Ammon HU (2002) Cover crops and living mulches. Weed Sci 50(6):688-699. https://doi.org/10.2134/agronj13.0402

Hayden ZD, Gouajio MN, Brainard DC (2014) Rye-vetch mixture proportion tradeoffs: cover crop productivity, nitrogen accumulation, and weed suppression. Agron J 106(3):904-914 https://doi.org/10. 2134/agronj2013.0467

Hiltbrunner J, Streit B, Liedgens M (2007a) Are seeding densities an opportunity to increase grain yield of winter wheat in a living mulch of white clover? Field Crop Res 102(3):163-171. https://doi.org/10. 1016/j.fcr.2007.03.009

Hiltbrunner J, Liedgens M, Bloch L, Stamp P, Streit B (2007b) Legume cover crops as living mulches for winter wheat: components of biomass and the control of weeds. Eur J Agron 26(1):21-29. https://doi.org/10.1016/j.eja.2006.08.002

Hobbs PR, Sayre K, Gupta R (2008) The role of conservation agriculture in sustainable agriculture. Philos Trans R Soc B Biol Sci 363(1491): 543-555. https://doi.org/10.1098/rstb.2007.2169

Jackson LE (1997) Ecology in Agriculture. Academic, Cambridge

Jani AD, Grossman J, Smyth TJ, Shuijin H (2016) Winter legume covercrop root decomposition and $\mathrm{n}$ release dynamics under disking and roller-crimping termination approaches. Renewable Agric Food Syst 31(3):214-229. https://doi.org/10.1017/S1742170515000113

Keene CL, Curran WS, Wallace JM, Ryan MR, Mirsky SB, VanGessel MJ, Barbercheck ME (2017) Cover crop termination timing is critical in organic rotational no-till systems. Agron J 109(1):272-282. https://doi.org/10.2134/agronj2016.05.0266

Kniss AR (2017) Long-term trends in the intensity and relative toxicity of herbicide use. Nat Commun 8(April):14865. https://doi.org/10. 1038/ncomms14865

Kornecki TS, Raper RL, Arriaga FJ, Balkcom KS, Price AJ (2005) Effects of rolling/crimping rye direction and different row-cleaning attachments on cotton emergence and yield. In: Proc. Southern Conservation Tillage Conf., 27th. Florence, SC, 27-29. Citeseer. http://citeseerx.ist.psu.edu/viewdoc/download?doi=10.1.1.535. 4042\&rep=rep1\&type=pdf. Accessed 20 February 2017

Kornecki TS, Price AJ, Raper RL (2006) Performance of different roller designs in terminating rye cover crop and reducing vibration. Appl Eng Agric 22(5):633-641. https://doi.org/10.13031/2013.21994

Kornecki TS, Price AJ, Raper RL, Arriaga FJ (2009) New roller crimper concepts for mechanical termination of cover crops in conservation agriculture. Renewable Agric Food Syst 24(03):165-173. https:// doi.org/10.1017/S1742170509002580

Kornecki TS, Price AJ et al (2010) Effects of different roller/crimper designs and rolling speed on rye cover crop termination and seed cotton yield in a no-till system. J. Cotton Sci 14(4):212-220. https:// pubag.nal.usda.gov/pubag/article $\cdot x h t m l ? i d=49378$. Accessed 20 February 2017

Kornecki TS, Arriaga FJ, Price AJ (2012) Roller type and operating speed effects on rye termination rates, soil moisture, and yield of sweet corn in a no-till system. HortScience 47(2):217-223. https://doi.org/ 10.21273/HORTSCI.47.2.217

Lal R (2015) Sequestering carbon and increasing productivity by conservation agriculture. J Soil Water Conserv 70(3):55A-62A. https:// doi.org/10.2489/jswc.70.3.55A

Landers JN, Challiol M, Vilela L, Lanz S (2016) Case study of zerotillage organic soybean production in Brazil. Soil Res 54(2):166172. https://doi.org/10.1071/SR15037

Lefebvre M, Leblanc M, Gilbert P-A, Estevez B, Grenier M, Belzile L (2011) Semis Direct Sur Paillis de Seigle Roulé En Régie Biologique. Rapport final 08 BIO-24 (IRDA-400063). Institut de 
recherche et de développement en agroenvironnement, Québec. https://www.agrireseau.net/agriculturebiologique/documents/ Rapport\%20Final_08-BIO-24\%20(IRDA-400063)\%20vf.doc. Accessed 3 August 2016

Lefevre V (2013) Conception de Systèmes de Culture Innovants Pour Améliorer Le Fonctionnement Des Sols En Agriculture Biologique. L'institut des sciences et industries du vivant et de l'environnement (AgroParisTech), Thiverval-Grignon https:// metafort.cemagref.fr/activites/theses-et-post-docs/theses-soutenues$1 /$ activites/theses-et-post-docs/theses-soutenues-1/files/lefevre 2013 manuscrit these.pdf. Accessed 3 January 2016

Légère A, Shirtliffe SJ, Vanasse A, Gulden RH (2012) Extreme grainbased cropping systems: when herbicide-free weed management meets conservation tillage in northern climates. Weed Technol 27(1):204-211. https://doi.org/10.1614/WT-D-12-00074.1

Liebert JA, Ryan MR (2017) High planting rates improve weed suppression, yield, and profitability in organically-managed no-till planted soybean. Weed Technol 31(4):536-549

Liebert JA, DiTommaso A, Ryan MR (2017) Rolled mixtures of barley and cereal rye for weed suppression in cover crop-based organic notill planted soybean. Weed Sci:1-14. https://doi.org/10.1017/wsc. 2016.23

Liebman AM, Grossman J, Matthew B, Scott Wells M, Reberg-Horton SC, Shi W (2018) Legume cover crops and tillage impact nitrogen dynamics in organic corn production. Agron J 110(3):1046-1057. https://doi.org/10.2134/agronj2017.08.0474

Liu A, Ma BL, Bomke AA (2005) Effects of cover crops on soil aggregate stability, total organic carbon, and polysaccharides. Soil Sci Soc Am J 69(6):2041-2048. https://doi.org/10.2136/sssaj2005.0032

Mäder P, Berner A (2012) Development of reduced tillage systems in organic farming in Europe. Renewable Agric Food Syst 27(Special Issue 01):7-11. https://doi.org/10.1017/ S1742170511000470

Mirsky SB, Curran WS, Mortenseny DM, Ryan MR, Shumway DL (2011) Timing of cover-crop management effects on weed suppression in no-till planted soybean using a roller-crimper. Weed Sci 59(3):380-389. https://doi.org/10.1614/WS-D-10-00101.1

Mirsky SB, Ryan MR, Curran WS, Teasdale JR, Maul J, Spargo JT, Moyer J et al (2012) Conservation tillage issues: cover crop-based organic rotational no-till grain production in the Mid-Atlantic Region, USA. Renewable Agric Food Syst 27(Special Issue 01): 31-40. https://doi.org/10.1017/S1742170511000457

Mirsky SB, Ryan MR, Teasdale JR, Curran WS, Reberg-Horton CS, Spargo JT, Scott Wells M, Keene CL, Moyer JW (2013) Overcoming weed management challenges in cover crop-based organic rotational no-till soybean production in the Eastern United States. Weed Technol 27(1):193-203. https://doi.org/10.1614/WTD-09-00004.1

Mirsky SB, Ackroyd VJ, Cordeau S, Curran WS, Masoud H, Chris Reberg-Horton S, Ryan MR, Spargo JT (2017) Hairy vetch biomass across the Eastern United States: effects of latitude, seeding rate and date, and termination timing. Agron J 109(January). https://doi.org/ 10.2134/agronj2016.09.0556

Mischler RA, Curran WS, Duiker SW, Hyde JA (2010a) Use of a rolledrye cover crop for weed suppression in no-till soybeans. Weed Technol 24(3):253-261. https://doi.org/10.1614/WT-D-09-00004.1

Mischler R, Duiker SW, Curran WS, Wilson D (2010b) Hairy vetch management for no-till organic corn production. Agron J 102(1): 355-362. https://doi.org/10.2134/agronj2009.0183

Mohler CL, Callaway MB (1995) Effects of tillage and mulch on weed seed production and seed banks in sweet corn. J Appl Ecol 32(3): 627. https://doi.org/10.2307/2404658

Motta AC, Reeves W, Burmester C, Feng Y (2007) Conservation tillage, rotations, and cover crop affecting soil quality in the Tennessee Valley: particulate organic matter, organic matter, and microbial biomass. Commun Soil Sci Plant Anal 38(19-20):2831-2847. https://doi.org/10.1080/00103620701663065

Moyer J (2011) Organic no-till farming. Advancing no-till agriculture. Crops, soil, equipment. Acres U.S.A, Austin, Texas: Copyright.

Nichols V, Verhulst N, Cox R, Govaerts B (2015) Weed dynamics and conservation agriculture principles: a review. Field Crop Res 183(November):56-68. https://doi.org/10.1016/j.fcr.2015.07.012

Parr M, Grossman JM, Reberg-Horton CS, Brinton C, Crozier C (2011) Nitrogen delivery from legume cover crops in no-till organic corn production. Agron J 103(6):1578. https://doi.org/10.2134/ agronj2011.0007

Parr M, Grossman JM, Chris Reberg-Horton S, Brinton C, Crozier C (2014) Roller-crimper termination for legume cover crops in North Carolina: impacts on nutrient availability to a succeeding corn crop. Commun Soil Sci Plant Anal 45(8):1106-1119. https://doi.org/10. 1080/00103624.2013.867061

Peigné J, Cannavaciuolo M, Gautronneau Y, Aveline A, Giteau JL, Cluzeau D (2009) Earthworm populations under different tillage systems in organic farming. Soil Tillage Res 104(2):207-214. https://doi.org/10.1016/j.still.2009.02.011

Peigné J, Lefevre V, Vian JF, Fleury P (2015) Conservation agriculture in organic farming: experiences, challenges and opportunities in Europe. In: Farooq M, Siddique KHM (eds) Conservation Agriculture. Springer International Publishing, Basel, pp 559-578. http://link.springer.com/chapter/10.1007/978-3-319-11620-4_21. Accessed 17 March 2016

Penha LAO, Khatounian CA, Fonseca ICB (2012) Effects of early compost application on no-till organic soybean. Planta Daninha 30(1):18. https://doi.org/10.1590/S0100-83582012000100001

Pittelkow CM, Linquist BA, Lundy ME, Liang X, van Groenigen KJ, Lee J, van Gestel N, Six J, Venterea RT, van Kessel C (2015) When does no-till yield more? A global meta-analysis. Field Crop Res 183(Supplement C):156-168. https://doi.org/10.1016/j.fcr.2015.07. 020

Place GT, Reberg-Horton SC, Dunphy JE, Smith AN (2009) Seeding rate Effects on weed control and yield for organic soybean production. Weed Technol 23(4):497-502. https://doi.org/10.1614/WT-08-134.1

Porter P, Feyereisen G, De Bruin J, Johnson G (2005) No-till organic soybean production following- a fall-planted rye cover crop. 2005. http://www.systems-comparison.fibl.org/fileadmin/documents/ shop/1394-research-sustainable-systems.pdf. Accessed 28 March 2017

Qi Z, Helmers MJ (2010) Soil water dynamics under winter rye cover crop in Central Iowa. Vadose Zone J 9(1):53-60. https://doi.org/10. 2136/vzj2008.0163

Reberg-Horton SC, Grossman JM, Kornecki TS, Meijer AD, Price AJ, Place GT, Webster TM (2012) Utilizing cover crop mulches to reduce tillage in organic systems in the Southeastern USA. Renewable Agric Food Syst 27(Special Issue 01):41-48. https://doi.org/10. $1017 / \mathrm{S} 1742170511000469$

Reicosky DC, Saxton KE (2006). Benefits of no-tillage. No-Tillage Seeding in Conservation Agriculture / C.J. Baker ... [et al.] ; Baker CJ, Saxton KE (eds). http://agris.fao.org/agris-search/search.do? recordID=US201301937252. Accessed 20 February 2017

Robb D, Zehnder G, Kloot R, Bridges W, Park D (2018) Weeds, nitrogen and yield: measuring the effectiveness of an organic cover cropped vegetable no-till system. Renewable Agric Food Syst:1-8. https:// doi.org/10.1017/S1742170517000795

Ryan MR (2010) Energy usage, greenhouse gases, and multi-tactical weed management in organic rotational no-till cropping systems. The Pennsylvania State University, State College https://etda. libraries.psu.edu/paper/11087/6783. Accessed 18 March 2017

Ryan RL, Erickson DL, De Young R (2003) Farmers' motivations for adopting conservation practices along Riparian Zones in a MidWestern agricultural watershed. J Environ Plan Manag 46(1):19 37. https://doi.org/10.1080/713676702 
Ryan MR, Curran WS, Grantham AM, Hunsberger LK, Mirsky SB, Mortensen DA, Nord EA, Wilson DO (2011) Effects of seeding rate and poultry litter on weed suppression from a rolled cereal rye cover crop. Weed Sci 59(3):438-444. https://doi.org/10.1614/WS-D-1000180.1

Schmidt JH, Junge S, Finckh MR (2019) Cover crops and compost prevent weed seed bank buildup in herbicide-free wheat-potato rotations under conservation tillage. Ecol Evol 9(5):2715-2724. https:// doi.org/10.1002/ece 3.4942

Silva EM (2014) Screening five fall-sown cover crops for use in organic no-till crop production in the Upper Midwest. Agroecol Sustain Food Syst 38(7):748-763. https://doi.org/10.1080/21683565.2014. 901275

Silva E, Delate K (2017) A decade of progress in organic cover cropbased reduced tillage practices in the Upper Midwestern USA. Agriculture 7(5):44. https://doi.org/10.3390/agriculture7050044

Silva EM, Vereecke L (2019) Optimizing organic cover crop-based rotational tillage systems for early soybean growth. Org Agric. https:// doi.org/10.1007/s13165-019-00243-9

Singh R, Subhash B, Avasthe RK, Yadav GS (2018) Integrating conservation agriculture in organic farming. 1: 16

Smith AN, Chris Reberg-Horton S, Place GT, Meijer AD, Arellano C, Mueller JP (2011) Rolled rye mulch for weed suppression in organic no-tillage soybeans. Weed Sci 59(2):224-231. https://doi.org/10. 1614/WS-D-10-00112.1

Soane BD, Ball BC, Arvidsson J, Basch G, Moreno F, Roger-Estrade J (2012) No-till in Northern, Western and South-Western Europe: a review of problems and opportunities for crop production and the environment. Soil Tillage Res 118(January):66-87. https://doi.org/ 10.1016/j.still.2011.10.015

Teasdale JR, Mohler CL (1993) Light transmittance, soil temperature, and soil moisture under residue of hairy vetch and rye. Agron J 85(3): 673-680. https://doi.org/10.2134/agronj 1993 . $00021962008500030029 x$

Teasdale JR, Devine TE, Mosjidis JA, Bellinder RR, Edward Beste C (2004) Growth and development of hairy vetch cultivars in the Northeastern United States as influenced by planting and harvesting date. Agron J 96(5):1266-1271. https://doi.org/10.2134/ agronj2004.1266

Teasdale JR, Coffman CB, Mangum RW (2007) Potential long-term benefits of no-tillage and organic cropping systems for grain production and soil improvement. Agron J 99(5):1297-1305. https://doi.org/10. 2134/agronj2006.0362

Tosti G, Benincasa P, Farneselli M, Pace R, Tei F, Guiducci M, ThorupKristensen K (2012) Green manuring effect of pure and mixed barley - hairy vetch winter cover crops on maize and processing tomato N nutrition. Eur J Agron 43(November):136-146. https://doi.org/ 10.1016/j.eja.2012.06.004

Triplett GB, Dick WA (2008) No-tillage crop production: a revolution in agriculture! Agron J 100(Supplement 3):S-153. https://doi.org/10. 2134/agronj2007.0005c

Uri ND (2000) Perceptions on the use of no-till farming in production agriculture in the United States: an analysis of survey results. Agric Ecosyst Environ 77(3):263-266. https://doi.org/10.1016/S01678809(99)00085-7

USDA-Economic Research Service (ERS) (2015) Certified Organic Survey. Retrieve from http://usda.mannlib.cornell.edu/usda/nass/ OrganicProduction//2010s/2016/OrganicProduction-09-15-2016. pdf. Accessed 10 June 2019

Vaisman I, Entz MH, Flaten DN, Gulden RH (2011) Blade roller-green manure interactions on nitrogen dynamics, weeds, and organic wheat. Agron J 103(3):879-889. https://doi.org/10.2134/ agronj2010.0437

Vann RA, Chris Reberg-Horton S, Poffenbarger HJ, Zinati GM, Moyer JB, Mirsky SB (2017) Starter fertilizer for managing cover cropbased organic corn. Agron J 109(5):2214-2222. https://doi.org/10. 2134/agronj2016.09.0506

Vian JF, Peigne J, Chaussod R, Roger-Estrade J (2009) Effects of four tillage systems on soil structure and soil microbial biomass in organic farming. Soil Use Manag 25(1):1-10. https://doi.org/10.1111/j. 1475-2743.2008.00176. $\mathrm{x}$

Villamil MB, Bollero GA, Darmody RG, Simmons WF, Bullock DG (2006) No-till corn/soybean systems including winter cover crops. Soil Sci Soc Am J 70(6):1936-1944. https://doi.org/10.2136/ sssaj2005.0350

Vincent-Caboud L, Peigné J, Casagrande M, Silva EM (2017) Overview of organic cover crop-based no-tillage technique in Europe: farmers' practices and research challenges. Agriculture 7(5):42. https://doi. org/10.3390/agriculture 7050042

Vincent-Caboud L, Vereecke L, Silva E, Peigné J (2019) Cover crop effectiveness varies in cover crop-based rotational tillage organic soybean systems depending on species and environment. Agronomy 9(6):319. https://doi.org/10.3390/agronomy9060319

Wallace J, Williams A, Liebert J, Ackroyd V, Vann R, Curran W, Keene C, VanGessel M, Ryan M, Mirsky S (2017) Cover crop-based, organic rotational no-till corn and soybean production systems in the Mid-Atlantic United States. Agriculture 7(4):34. https://doi.org/10. 3390/agriculture704e0034

Wallace JM, Keene CL, Curran W, Mirsky S, Ryan MR, VanGessel MJ (2018) Integrated weed management strategies in cover crop-based, organic rotational no-till corn and soybean in the Mid-Atlantic Region. Weed Sci 66(1):94-108. https://doi.org/10.1017/wsc.2017.53

Weber J, Kunz C, Peteinatos G, Zikeli S, Gerhards R (2017) Weed control using conventional tillage, reduced tillage, no-tillage, and cover crops in organic soybean. Agriculture 7(5):43. https://doi.org/10. 3390/agriculture 7050043

Wells MS, Reberg-Horton SC, Mirsky SB (2014) Cultural strategies for managing weeds and soil moisture in cover crop based no-till soybean production. Weed Sci 62(3):501-511. https://doi.org/10.1614/ WS-D-13-00142.1

Wells SM, Brinton CM, Reberg-Horton SC (2015) Weed suppression and soybean yield in a no-till cover-crop mulched system as influenced by six rye cultivars. Renewable Agric Food Syst (September):1-12. https://doi.org/10.1017/S1742170515000344

Williams A, Scott Wells M, Dickey DA, Hu S, Maul J, Raskin DT, Chris Reberg-Horton S, Mirsky SB (2018) Establishing the relationship of soil nitrogen immobilization to cereal rye residues in a mulched system. Plant Soil 426(1):95-107. https://doi.org/10.1007/s11104018-3566-0

Wyse DL (1994) New technologies and approaches for weed management in sustainable agriculture systems. Weed Technol 8(2):403407. https://doi.org/10.1017/S0890037X00039014

Zikeli S, Gruber S (2017) Reduced tillage and no-till in organic farming systems, Germany-status quo, potentials and challenges. Agriculture 7(4):35. https://doi.org/10.3390/agriculture7040035

Zinati GM, Seidel R, Grantham A, Moyer J, Ackroyd VJ, Mirsky SB (2017) High-residue cultivation timing impact on organic no-till soybean weed management. Weed Technol 31(2):320-329. https:// doi.org/10.1017/wet.2016.24

Publisher's note Springer Nature remains neutral with regard to jurisdictional claims in published maps and institutional affiliations. 